who were associated with the early work on insulin, and referred to the desire of Canadians to be in touch with 'the old land'. He said that, as professor of medical research in the University of Toronto, he saw research students passing away from the University; in one year forty-five per cent of the graduates of the University went to the United States; nevertheless their bond with the British Empire was stronger than with America; their desire was to become more British. He asked that Canadian students should be made kindly welcome in Britain in order that their sentiments of kinship might be made stronger. In Canada they are endeavouring to send their students to Britain, for the great thing about British medicine is that it rests on a solid foundation. Traditions are only beginning in Canada ; in this respect there is a great difference from Britain. The Canadian who comes over here takes back with him on his return some of the high traditions which guide men in Great Britain. The bonds of fellowship are stronger and more enduring than financial inducements, which are a source of weakness. Sir Frederick's great wish is that the ties with Britain should be strengthened.

\section{The Quetta Earthquake}

FEW details of scientific interest have as yet reached England from the Quetta district. Shocks of course continue to be felt, some of them strong enough to bring down walls left standing among the ruins. The destruction of Quetta City is almost complete. Landmarks of all kinds have disappeared, and the city is a widespread mass of debris. An official report gives the number of killed in it as 26,000 out of a population of 40,000 . In addition to the towns of Kalat and Mastung, at least one hundred villages have been totally destroyed within a band 130 miles long and 20 miles wide, the number of killed in them being estimated as between 12,000 and 15,000 , so that the total number of deaths is probably about 40,000 . So impossible is it to excavate the dead bodies in Quetta City that all the survivors have been removed in fear of an outbreak of disease. The city has been surrounded by barbed-wire entanglements and will be protected by guards in order to save the property of survivors from marauding tribesmen; it is intended that the city shall remain so sealed for a whole year.

\section{International Co-operation in Americanist Studies}

An important proposal for the promotion of studies in American ethnology and colonial history on an international basis is to be submitted to the next General Assembly of the League of Nations. It originated with M. Levillier, delegate of the Argentine, who proposed to the last General Assembly that arrangements should be made for the publication by international co-operation of a series of original and authoritative works dealing with the indigenous peoples and cultures of the Americas and with the history of the discovery, geographical exploration, conquest, settlement and colonial government of the continent in the sixteenth century. The proposal was approved in principle and referred to the International Institute of Intellectual Co-operation for consideration and report on the organisation and financial arrangements necessary to give it effect. Such a scheme has now been prepared by a committee of Americanists appointed by the International Institute. The Committee is a strong body of distinguished diplomatists and historians; but as much stress is laid on the importance of the ethnology of America and the history of indigenous cultures, it is a little surprising to find that anthropology is represented on the Committee by one member only. Although that member, M. Paul Rivet, is a host in himself, it might, perhaps, have been expected that some, at least, of the numerous distinguished authorities on American ethnology and culture would have been included in the list of those consulted by correspondence, where Prof. Stolyhwo of Warsaw appears as the only anthropologist.

The suggestions of the Committee provide for the publication of, approximately, fourteen volumes dealing with indigenous ethnology and culture, and fifty dealing with the historical side of Americanist studies. These volumes would be published over a period of years at the rate of, say, four a year, two in ethnology and two in history. In a comprehensive and detailed synopsis of topics, the subject-matter has been classified into six sections, of which the first covers the geology and natural history of America and the archæology, physical anthropology, demography and culture of the Indians. The remaining five sections cover European relations with America before and after the Spanish discovery, the history of the discovery and exploration of the various parts of the continent, the conquest, the colonial period and administrative, social, religious and economic organisation during the sixteenth and down to the beginning of the seventeenth century from all points of view. The preparation of the volumes, which will appear in English or French, and will be in the nature both of monographs on specific points of research and treatises of a synoptic and general character, will be entrusted to scholars of admitted and international repute. The general aim of the Committee in preparing the scheme has been to promote the better mutual understanding of the peoples of the Americas and Europe and at the same time to remove popular misconceptions as to the methods and aims of the conquistadores and early colonists. While the Committee is unable to suggest precisely the price at which volumes should be published, as this must vary according to the amount of illustration, it mentions as an approximate figure 60 francs, with a subseription price of 40 franes, and invites advance promises to subscribe in order to facilitate consideration of its proposals.

\section{Origin of Man Again}

Aт the Victoria Institute or Philosophical Society of Great Britain, on March 25, Mr. Douglas Dewar read a paper entitled "A Critical Examination of the supposed Fossil Links between Man and the Lower Animals". The paper contains no critical examination 
of any of the fossils, but it shows how expert opinion has differed regarding the interpretation of the relationships of the relatively fow specimens which have been found. The interpretation of fragmentary fossils is a ticklish business (witness the controversy regarding the significance of the Caithness fossil Palceospondylus, notwithstanding that scores of complete specimens are known), so that no one need be unduly disturbed by different interpretations of anthropoid fragments. Nevertheless, Mr. Dewar correctly sums up the position when he states that "science can truthfully say that it knows not when, where or how, man originated"; but he understates the truth when he says that this is all that science knows, for although there is "no conclusive evidence that any Primate genus has been transformed into any other genus", there are resemblances in detail and gradings which require much explana. tion if transformism is to be rejected. To say that "each new type appears in the rocks having all its characteristics, as if it had migrated from some other locality", simply pushes the problem back to the 'other locality'. How did it originate there ?

\section{Special Creation or Evolution?}

Mr. Dewar does not say so, but probably he would agree with the view of the president of the Victoria Institute, Sir Ambrose Fleming, that man and every other genus began as a special creation. In support of that thesis, Sir Ambrose regards the Java, Heidelberg, Piltdown and Pekin 'men', as biological abnormalities, passing over the probabilities against the disappearance of all the normal forms of their time, and the preservation of abnormalities only. He holds that "if nearly as many [human] individuals die as are born in a year, there can be no particular contest for food and one of the factors in the Darwinian causes of evolution is thereby removed" ("Modern Anthropology versus Biblical Statements on Human Origin". Second edition. London: Victoria Institute, 1935. 1s.) But this mortality rate is what actually happens in every stable species of plant and animal, and the enormous destruction has generally been regarded as affording just that opportunity for selection which Darwin postulated. These and other aspects of the antiDarwin controversy are dealt with in a lively booklet by Sir Arthur Keith, "Darwinism and its Critics" (The Forum Series, No. 20. Pp. vii +56. London : Watts and Co., 1935. Paper, 7d. net; cloth, 1s. net), in which he defends the theory of evolution against the arguments of Sir Ambrose Fleming, and of other critics, some obviously ill-informed as to the facts. Sir Arthur clings to his hard-hitting style, but his punches are clean, and he swings a good knock-out. Also he adheres to the adage of a recent school grammar book-"explain clearly, as if to a Scotsman ..."

\section{London Television Station}

THE Postmaster-General announces that the Television Advisory Committee has recommended the adoption of the Alexandra Palace for the London
Television Station. This recommendation has been approved by the Postmaster-General; and the British Broadcasting Corporation has made arrangements with the Alexandra Palace trustees for the use of a portion of the buildings for the station. The ground at the Alexandra Palace is $306 \mathrm{ft}$. above sealevel; and it is proposed to erect a $300 \mathrm{ft}$. mast on the site, thus providing an aerial height of $606 \mathrm{ft}$. above sea-level which, it is considered, should enable a high definition television service to be provided for the London area. The Baird Television Company and the Marconi-E.M.I. Television Company are being invited to tender for the supply of the necessary apparatus for the operation of their respective systems at the station. The Baird Company proposes the adoption of a standard of picture definition of 240 lines sequential scanning, 25 picture traversals a second, 25 complete frames a second; and the Marconi-E.M.I. Company propose a standard of 405 lines, 25 pictures a second, interlaced to give 50 frames a second, each of $202 \frac{1}{2}$ lines. The Committee proposes that the vision signals shall be radiated on a wave-length of about $6 \cdot 6$ metres and the associated sound signals on a wave-length of about $7 \cdot 2$ metres.

\section{Television in Germany}

A REGULAR television transmission service has already been inaugurated in Berlin by the German Post Office authorities, and arrangements are made whereby the public can attend demonstrations so that they may see for themselves what the new service has to offer. An article describing the proposals for the further development of television in Germany was given in the Wireless World of May 24, as an abstract of a paper by W. Scholz, recently published in Elektrische Nachrichten Technik. The television transmissions are of the $180 \operatorname{line,} 25$ pictures per second type and are given on ultra-short waves of less than 8 metres. Both sound and vision transmissions take place on these wave-lengths, so that a single heterodyne oscillator may be used at the receiver for both portions of the programme. A total band-width of 2,400 kilocycles per second is allocated to each station for the combined programmes. In the scheme proposed, it is assumed that a minimum field-strength of 1 millivolt per metre has to be provided, and that the transmitters will have aerial powers of from 2 to 20 kilowatts on wave-lengths between $5 \cdot 7$ and $7 \cdot 5$ metres. The lower-power stations will be erected on mountain peaks at heights ranging up to $4,000 \mathrm{ft}$., and it is estimated that the effective range of these stations will be of the order of 85 miles. On this basis, it is considered that the whole of Germany can be provided with a television service by means of twenty to thirty stations, the wave-lengths being distributed geographically so as to avoid mutual interference.

\section{Progress in the Gas Industry}

THE seventy-second annual general meeting of the Institution of Gas Engineers was held in London on June 4-7 under the presidency of Mr. C. Valon Bennett of Rochester. He reviewed the present 